\title{
Uncivil Society, or, Orientalism and Tiananmen, 1989
}

\section{Daniel F. Vukovich}

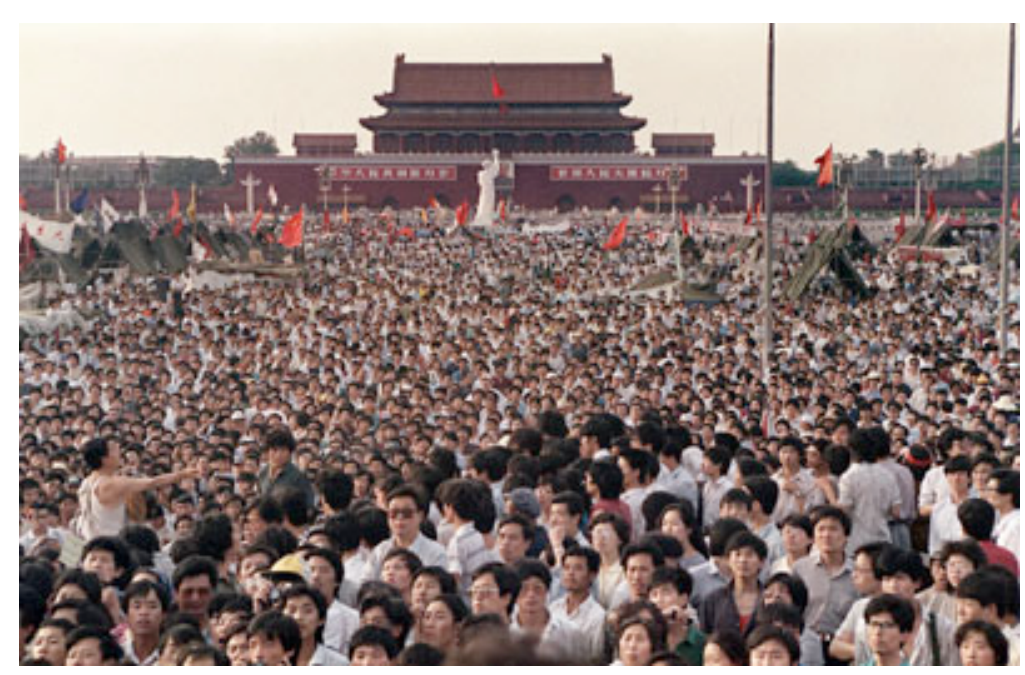

In the current conjuncture, typified as much by the seemingly irresistible rise of China as by the U.S. imperium, the social force called orientalism knows a new lease on life. By way of an extended reading of the 1989 Tiananmen protests I will argue that there exists a new, Sinological form of orientalism at work in the world. Ranging from academic to media and state-policy circles, it emerges where Edward Said's disseminative account from1978 leaves off: the moment when orientalism completes its migration from Europe and philology to U.S.-based social sciences and "area studies," to the pax Americana and a closer relation to the logic and policies of the state. Nineteen seventy-eight also marks the end of the uncertain Hua Guofeng era within China, the subsequent rise of Deng Xiaoping and the unleashing of the power of capital within China. Deng led not just an ideological but a material de-Maoification, systematically eliminating every last vestige of leftist institutions, save the Party itself. Deng's capitalistic policies and his de-politicization of state cultural and academic spheres were warmly received not just by the Western powers and corporations who now had access to the fantasy of one-billion consumers, but emphatically so by China Studies. For Sinologists it was now open season on China and for the production of "new" knowledge 
about a China awakening yet again. ${ }^{1}$ (The specter of a somnambulant China who might actually wake up is as old as Napoleon and as recent as the editorial page of the New York Times.) From this global yet orientalist perspective, shared by some of the liberal Chinese intelligentsia and vulgar modernizers like Deng as much as by area studies, China was en route to becoming "normal." The Other was finally changing and entering real history.

Within this new form of orientalism, China is seen as rapidly evolving from primitive, communist (and "despotic") Other to our distant cousin, one who is, willy-nilly, becoming-Western, becoming-“modern." Put another way, China is graspingly putting its "Asiatic" past behind, becoming generally equivalent to the West. Recall that for Said orientalism posits the Other as radically and essentially different: different in psychology, custom, politics (“despotism”), sexuality, mind, and so on. As Kipling put it, "East is East, and West is West, and never the twain shall meet." Or as Said summarizes: orientalism is a "style of thought based upon an ontological and epistemological distinction between 'the Orient' and (most of the time) 'the Occident"'(2). But with the case of post-Mao, "reform era" China this form of orientalism turns upon its object of study - China and its victimized but "dissenting" masses - graspingly but inevitably becoming the Same as "we." That is, they are following in "our" wake, becoming the same as we modern, free subjects of an "open," liberal nation-state and "civil society," a teleological process which will, someday, follow from their capitalistic economy.

This Sinological form of orientalism marks a shift from the differentialist logic that Said documented, to one now turning upon sameness (the becoming-sameness of China). As befits the world system today, it also follows a capital logic of general equivalence. This historical shift has consequences as a critique of Said's and post-colonial studies' model of orientalism, for it shows us that they fail to deal with one of the principal contradictions of modern colonialism, namely, that in some absolutely crucial instances and projects - e.g., missionary projects, modernization theory - it is not simply allowed but mandated that the Other become the same, that it enter a process of

\footnotetext{
1 "Sinology" and "China Studies" are in this essay synonymous. I wish to suggest that, as an institution, the latter is just as anti-intellectual and subjective as the much older, often explicitly colonial and
} 
becoming-the-same. That is, despite the sense of difference between one location of the "Orient" and the outside observer an opposite logic - an opposite ontology and epistemology, one now rooted in equivalence - prevails. And yet if this much has changed within this new orientalism, its effects are in some crucial ways familiar: not only is it a misrepresentation of the P.R.C. and a part of a global and uneven production of knowledge that favors the West; it also produces what counts as the "Real China." 2 It also retains the key rhetorical strategy of orientalism as Said theorized it: the positional superiority of the China watcher (or expert) such that China or things Chinese are never allowed to gain the upper hand by challenging received categories of thought. In other words, the social realities, texts or contexts that the intellectual confronts are never allowed to make a difference in the production of (Sinological) knowledge. That there might be an incommensurability between Western theory or the methods of a discipline and the foreign reality is a very remote if not impossible notion within orientalism and mainstream China Studies. Nowhere are the problems of "traveling theory" broached and rarely if ever are contrasting, "local" knowledges consulted.

The bulk of this essay will deal with the Tiananmen protests, and will argue that their interpretation by China studies and by the Western media are emblematic of this new form of Sinological-orientalism. This last turns upon traditional figures of colonial discourse - e.g., despotism, passive and irrational "native" subjects - but the shift to sameness is brought home by the new dominance of social science rhetoric, in particular its emphasis on China now, or in the near future finally producing a civil society and liberal individuals, and thereby following a "universal" pattern of modernization. Rather than just being an affair of area studies, this orientalism, I argue, is part of the U.S.-West's social imaginary, and of contemporary intellectual-political culture. Tiananmen as the truth of civil society "after Mao" has less to do with China than with the self-image of the West and its exceptionalism.

\footnotetext{
"unscientific" Sinology. In Europe "Sinology" like "Oriental" is still current usage.

${ }^{2}$ Real China: From Cannibalism to Karaoke (New York: Simon and Shuster, 1996) is the supremely confident title of a book by long-time British China Watcher John Gittings.
} 


\section{Tiananmen, 1989 in Western Minds}

Since the end of the Mao era, there has been one event - a global media event which has most forcefully secured the place of China within "Western minds." (My use of the latter phrase is meant to mark the type of semantic violence that subtends an old phrase of orientalism: the Chinese mind.) I refer of course to the 1989 Tiananmen protest movement, including the killings that concluded it. For viewers ranging from $\mathrm{CNN}$ to Marxism Today, ${ }^{3}$ those Spring events of 1989 represent a victimized Chinese people's thwarted attempt to enter political and social modernity, to achieve a liberal democracy and civil society alongside their newly-free markets, or in sum to finish a telos that was rudely interrupted by - in the words of one Cold Warrior journalist - the "new emperors," Mao and Deng. ${ }^{4}$

While in the initial decades after 1989 there was an enormous amount of scholarship on the movement, there has been scant critique of specifically "Western" understandings of the events. In fact within China Studies Dingxin Zhao's recent book, The Power of Tiananmen, marks the first full-on engagement of Western Sinologist's work on Tiananmen. Zhao's meticulous sociological study makes this critique as much by pointed omission as by direct engagement with the most widely reputed of English language Sinology's doyens. At least that is how the book has been received. Thus Jeffrey Wasserstrom takes him to task simply for not citing the work of Geremie Barme, a prolific, famously fluent but also notoriously condescending critic of virtually all things Chinese: “This wouldn't matter except that some specialists (myself included) think him [Barme] among the most consistently insightful and on-target analysts of Chinese culture and politics" ("Backbeat" par. 18). While Wasserstrom grounds his criticism in only the proper name of Barme, Elizabeth J. Perry rejects Zhao's own rejections of culturalist and “elite factionalist" approaches to 1989. What emerges most sharply in Perry's response

\footnotetext{
${ }^{3}$ See Gareth Steadman Jones, "The Crisis of Communism," in New Times: The Changing Face of Politics in the 1990s (Ed. Martin Jacques and Stuart Hall. London: Lawrence and Wishart, 1989). Jones refers to the CCP "abdicating" its "mandate from heaven," for want of "any source of legitimacy in civil society" (230). Such "civil society discourse" flourished in Europe in the wake of the dissident movement in Poland and Czechoslovakia, radically different contexts than that of China.

${ }^{4}$ See Harrison Salisbury, The New Emperors: Mao and Deng (New York: Little Brown, 1992).
} 
to Zhao is that he has committed the sin of dismissing the major contributions of some of Sinology's luminaries, from former CIA consultant Lucian Pye to Roderick MacFarquhar. Perry concludes that "for a book bold in its criticism of alternative analytical approaches and parsimonious in its acknowledgment of the contributions of previous scholarship, one might be forgiven for expecting a little more methodological rigor" ("Response" 185). Yet Zhao's book is indeed a reflexive one, and it is specialized Sinologists like Perry who rely on a pre-theoretical empiricism. Zhao analyzes how built-space on Beijing campuses literally enabled the movement and examines the social construction of public opinion in the square. This certainly marks an advance against the China field's Anglo-American hostility to theory. Thus Perry's point about "rigor" must actually be a point about something else: Zhao's rejection of Sinology as something not very useful for understanding Tiananmen. The point here is that if the first book to rebuke China studies' approaches to 1989 meets with such intransigence, it is less surprising that the crucial questions of how "we" see contemporary China have so far gone begging within the China field.

In regard to 1989 this absence of discussion about epistemology and ideology in the forming of knowledge is all the more unfortunate. For in addition to the sheer complexity of the event, Tiananmen was the first and perhaps the most enduring "live" global media event. In many ways, the true victor of the tragedy was the U.S. Cable News Network. Contra an area studies that has yet to question its mediated sources of information, the televisual transmission of Tiananmen can hardly be assumed to be a neutral medium. Those images have become emblematic of what counts as post-Mao China - its real people so to speak, and the real, remorseless machinery of state oppression. Thus Time magazine includes on its list of "Top 100 People of the Century," the anonymous Tank Man who, plastic shopping bag in hand, seemingly held off a row of PLA tanks by zigzagging with their movement and refusing to step off, until some bystanders pulled him away. ${ }^{5}$ In short, it was during that Spring that "we" learned that "the" Chinese were not only unhappy with Deng Xiaoping (Time's "Man of the Year" in 1984 and 1985) but were in effect "Americans in disguise" demanding our democracy,

\footnotetext{
${ }^{5}$ See Richard Gordon's brief words on him, “One Act, Many Meanings” (Media Studies Journal 13.1 Winter 1999: 82). Still an unknown figure, several have claimed to be him, just as Benetton and the
} 
using our symbols (the famous Goddess of Democracy statue), even quoting Patrick Henry (“Give Me Liberty or Give Me Death!” was a favorite slogan), and dying to be free of totalitarianism (Zizek, "Against" 80). While Sinologists relish the opportunity to deride yesterday's progressive or sympathetic scholarship on China's revolution, ${ }^{6}$ they have yet to be bothered with any methodological concern over their own embrace of this new "New China" and its "liberalizing," "becoming-modern" movement into Americanization.

It thus falls to the unlikely figure of Slavoj Zizek, in an otherwise rank essay pleading for the virtues of Eurocentrism and the Western origin of democracy, to give the lie to this fantasy. Referring to commentary on the velvet revolutions of the former socialist states of the East, he notes:

They saw in them the confirmation that the people of the East wanted what people in the West already had; that is, they automatically translated these demands into the Western liberal democratic notion of freedom (the . . . political game cum global market economy). Emblematic was the figure of Dan Rather, the American news reporter, on Tiananmen Square in 1989, standing in front of the copy of the Statue of Liberty [sic: Goddess of Democracy] and claiming that this statue said it all about what the protesting students demanded (in short, if you scratch the skin of a Chinese person, underneath you find an American) ("Leftist Plea" par. 23).

Drawing on Etienne Balibar's notion of "egaliberte," the "unconditional demand for freedom and equality that explodes any positive social order," Zizek thus indicates how Rather et al. re-inscribed this desire "into the confines of a given order" (liberal democratic capitalism) (par. 23). So too the perception that the Goddess statue "says it all" is a classic example of ideology at work, for as Althusser succinctly put it, ideology

Chinese authorities have used his image to their own ends.

${ }^{6}$ See Steven Mosher's China Misperceived (New York: Basic Books, 1990) and the contributions to the "Trends in China Watching" symposium at $<$ http://www.gwu.edu/ sigur/assets/docs/scap/ SCAP7-Trends.pdf $>$. As Arif Dirlik and Maurice Meisner note: "The dominant ideological orientation ... . is all the more powerful because its negative assessments of socialism in China . . . are not offered in explicit arguments but rather find expression in a general orientation that is more a "structure of sentiment" than one of ideas. This consists of an allegation here and a suggestion there and takes hold of our 
works by interpellating obviousnesses as such. ${ }^{7}$ One can see this ideological reinscription still at work in a recent Asia Times article:

I was never more proud to be an American than when the Goddess of Democracy statue, with its stunning resemblance to Lady Liberty ... made its way through Tiananmen Square. That made it all the more frustrating to see and hear the protest leaders bungle the principles for which they presumably stood. ${ }^{8}$

This unhesitatingly assimilates the Goddess statue to the author's own imaginary, and one-ups Rather in colonialist prerogative: not only was it "our" symbol, but the natives got it all wrong, and they simply must get it right the next time. The latter attitude further calls to mind Western Marxist codings of Maoist China, whereby the Chinese like the Soviets before them and everyone else afterwards, distorted if not betrayed Marxism that is, the real, authentic Marxism as it exists solely in the heads of Western Marxists, from the Frankfurt School to Trotskyism. My interest here is not in some contentless "egaliberte" nor on the alleged "utopian longing" Zizek sees at work in Tiananmen, but on the process of re-inscription. The coding of the Tiananmen events back into another given social order recalls one of the crucial features of orientalism, namely, that in the last instance it is about the self-constitution and identity of the West.

Indeed, so strong is the impression that they were - almost - "our" dissidents and analogues, that the country-wide protests over the bombing of the Chinese Embassy in Belgrade on May $7^{\text {th }} 1999$ were roundly condemned as a regression from 1989. If the Statue of Liberty reappears, but now coated in blood-red paint and draped in a swastika (as it did), then civil society must be over-run with irrational, frenzied nationalists, manipulated by the state. But scholars and the media linked the two events, and returned to the theme of China's long march to civil and modern society. For others 1989 was brought up but only to make the claim that the anti-NATO movement should not be compared to that because the former was real and spontaneous and the latter government-

consciousness." "Politics, Scholarship, and Chinese Socialism" 7.

${ }^{7}$ See "Ideology and Ideological State Apparatuses," especially 171-2. Lenin and Philosophy. Trans. Ben Brewster. New York: Monthly Review Press, 1971. 127-86.

${ }^{8}$ Gary LaMoshi, "Echoes of Tiananmen." Asia Times Online 4 June 2003. < http://www.atimes.com/ atimes/China/EF04Ad02.html>. 
organized or at least induced. "Civil society" remains the yardstick. In New Left Review, the self-professed "flagship journal of the English language left," Wasserstrom frames the two protests as a sign that, anti-U.S. and so-called "xenophobic" rhetoric notwithstanding, the Chinese were still developing properly, and will eventually establish a truly liberal, cosmopolitan, and anti-regime pubic sphere and civil society (Student 65). ${ }^{9}$ Wasserstrom sees 1989,1999 , and the hope of China as resting in the latter, and I will return to this dominant coding of post-Mao China below. But here note that his historical overview's key dates are all before and after Mao: from the Nationalist era of Generalissimo Chiang to the mid-1980s. Wasserstrom skips the long revolution itself and the first three, radical decades of the People's Republic. He instead grounds his analysis on the brief period - if the mid-1980s can be called that - which best fits the Western civil society narrative. In a later piece in the same journal, Wasserstrom says much the same about a dialogue on the meaning of 1989 between three prominent participants turned U.S. academics (Wang Dan, Li Minqi and Wang Chaohua). In the manner of a colonial, Oxbridge authority, he refers to their debate as "commendable" yet "wanting" because their accounts did not quite fit "with [his] own vision of 1989," and because they paid "too little attention" to what he has already decided are the "two particularly relevant periods in China's history" (the pre-War Republic and the mid-1980s) (W 63). The fact that Wasserstrom can so easily dismiss the analyses of three actual democracy activists and fault them for being ignorant of their own history says it all.

There is much that could be said about Wasserstrom's (and others') modernizing periodization here, but in regard to orientalism the crux of the matter is that these rhetorical moves perfectly illustrate positional superiority. The Mao era is simply not up for discussion, despite the fact that it literally un-formed and re-formed much of Chinese culture and politics. What is elided here is the very heart of the Maoist project in China: the pursuit, quite historically unprecedented, of an alternative modernity. As Liu Kang and Arif Dirlik have argued, and notwithstanding its grave mistakes and its foreclosure by Deng, Chinese Maoism was an active, real alternative to both Soviet and American

\footnotetext{
${ }^{9}$ It is no accident that the trope of an alleged Chinese xenophobia has its roots in the $19^{\text {th }}$ Century Chinese resistance to missionaries and imperialists.
} 
"development" and modernity. Signs of this alternative are easily indexed: the Maoist project of "Sinifying Marxism"; the radically egalitarian social policies centered on co-operative rural development; the creation and empowerment of an urban proletariat; the attempt to redress the rural/urban and manual/intellectual labor split; the distinctively Maoist passion for the masses; the ethos of self-reliance and the refusal of the pax Americana; and the attempt, desired in China since the Nineteenth Century, to produce nothing less than a new culture. All of this was not mere state rhetoric, but deeply held belief and part of a popular Maoist discourse and - moreover - were actually, if all too briefly institutionalized. As Zhang Xudong has noted, Sinologists as well as the Chinese liberal intelligentsia have yet to come to terms with the fact that the Cultural Revolution remains China's most significant era of participatory democracy. ${ }^{10}$ Thus any periodization of democratic movements in China should have to engage this era. So too it influenced 1989 when students and workers referenced Mao and Cultural Revolution era slogans (even when their point was to say how the student movement was unrelated to that). ${ }^{11}$ Thus neither the experiences nor the project of the Mao era are allowed to challenge Sinological knowledge, including the truth of Tiananmen as-civil society-as-modernization. From here this essay will offer a critique of this last coding. But it is a critique meant to serve another, simultaneous purpose: to reframe Tiananmen as in part rooted in the deeply political and deeply complex history and experience of the Mao era and its recent negation by the rise of capitalism in China. The immanent critique of orientalism, if it is to be more than the analysis of stereotype and colonial discourse, also has to proceed - contra Said - by way of an analysis of the historical and cultural complexities that are negated by the former.

\section{Overview of the Protests}

Since Tiananmen is so widely invoked yet little studied, it is worth recalling a basic narrative of the protests, before delving further into their place within

\footnotetext{
${ }^{10}$ Zhang Xudong, "Nationalism, Mass Culture, and Intellectual Strategies in Post-Mao China." (Social Text 16.2 Summer 1998: 109-40). See as well James R. Townsend, Political Participation in Communist China for the previous decades (Berkeley: UCB Press, 1969).

${ }^{11}$ On the GPCR and later democracy movements, see Lee Feigon, China Rising (Chicago: Ivan R. Dee,
} 
Sinological-orientalism. ${ }^{12}$ They are typically dated from April 15, with the death of $\mathrm{Hu}$ Yaobang. Hu was former heir to Deng Xiaoping but was purged in 1987 in an "anti-bourgeois liberalization" campaign for being far too enamored of Westernization/marketization and as payback for purging unrepentant Maoists or so-called hard-liners remaining in the party. For the students Hu's death merely provided the occasion to move up the demonstrations they had already been planning to commemorate the $70^{\text {th }}$ anniversary of the May 4th Movement, a long standing occasion for commemorative protest. The chief characteristics of the context of 1989 include runaway inflation in a stagnating economy; massive rural migration to the cities (a result of de-collectivization); skyrocketing unemployment in the State Owned Enterprises; rampant official corruption; and the ideological ferment of political and cultural activity on campuses and beyond. These last ranged from the "democracy salons" at the universities, and open letters from several intellectuals calling for an amnesty for all "political prisoners," to the more radical "Mao craze" and "cultural fevers" that pre-occupied many others. ${ }^{13}$ Thus one needs to recognize that the China of the early 1980s was - as always - far from a scene of mass conformity and control, and the protests were anything but a spontaneous manifestation of dissent, utopian longing, or millennial Zeitgeist.

Within hours of Hu's death, posters were put up mourning him, calling for his second rehabilitation (he was first purged during the $\mathrm{CR}$ ), railing against corruption, and

1990), as well as his Mao: A Re-interpretation (Chicago: Ivan R. Dee, 2002).

${ }^{12}$ The key collections of documents are: Lu Ping et al., A Moment of Truth: Workers' Participation in China's 1989 Democracy Movement, and the Emergence of Independent Unions (Trans. Gus Mok et al. Hong Kong: HK Trade Union Education Centre, 1990); Mok Chiu Yu et al., eds., Voices from Tiananmen Square (Montreal: Black Rose Books, 1990.); Han Minzhu, ed., Cries For Democracy: Writings from Tiananmen Square (Princeton: Princeton UP, 1990); Michael Oksenberg et al, eds., Beijing Spring, 1989 Confrontation and Conflict: The Basic Documents (New York: M.E. Sharpe, 1990) and Suzanne Ogden et al., eds., China's Search for Democracy: The Student and Mass Movement of 1989 (New York: M.E. Sharpe, 1992). The most detailed history is Zhao, Power of Tiananmen. In addition to other studies referred to below, Feigon's China Rising and William Hinton's The Great Reversal: The Privatization of China, 1978-1989 (New York: Monthly Review Press, 1990) stand out.

${ }^{13}$ See Jing Wang, High Culture Fever: Politics, Aesthetics, and Ideology in Deng's China (Berkeley: UCP, 1996), Zhang Xudong, Chinese Modernism In the Era of Reforms (Durham: Duke UP, 1997), and Geremie Barme's collection of texts from the Mao revival, Shades of Mao: The Posthumous Cult of the Great Leader (Armonk, New York: M.E. Sharpe, 1996). Kalpana Mishra in From Post-Maoism to Post-Marxism: The Erosion of Official Ideology in Deng's China (New York: Routledge, 1998) and Liu Kang in Aesthetics and Chinese Marxism: Chinese Aesthetic Marxists and Their Western Contemporaries (Durham: Duke UP, 2000) provide rich descriptions of the intellectual milieu. 
appealing for a greater role for education and intellectuals. Over the following weeks and days the number of posters would explode and their content would move from Hu's fate to more political and more specific demands, often attacking Deng Xiaoping and Li Peng (who would later declare Martial Law on May 28). The first demonstrations in the square were sparsely attended and did not escalate until after the "Xinhua Gate Bloody Incident" of April $20^{\text {th }}$. At this gate to the Central Committee's offices students demanded dialogue but wound up fighting the police. The incident triggered class boycotts and further demonstrations (Zhao 150). From here the next key moment was Hu's state funeral on April $22^{\text {nd }}$ which the students, over 50,000 strong in the square, were blocked from attending. After dialogue with officials, perhaps best remembered via three students' kneeling on the steps of the Great Hall of the People to deliver a petition (a gesture Geremie Barme codes as "feudal"), student leader Wuer Kaixi secured a promise to have the students' one, final demand met: for Li Peng to step out and talk. Peng did not. Hence the great anger and trauma (many students cried over this) and hence the emergence of new student organizations and the radicalization of the movement. ${ }^{14}$

A call for a citywide class boycott was announced, and protests continued on campuses and in the square. The regime issued its first public response: a denunciation of the anti-government "turmoil" (a code-word to signify the Cultural Revolution) carried out by an "extremely small" number of people. Broadcast on television and then printed as the April 26 editorial of People's Daily, this enraged the students because it accused them of being unpatriotic. It immediately led to large-scale demonstrations on the $27^{\text {th }}$, carried out by tens of thousands. By April $29^{\text {th }}$, the government started several dialogues with students. While amiable in tone the initial dialogues lacked substance and led nowhere. ${ }^{15}$ But it is worth noting that the government did concede the students' basic demand for recognition and acknowledged their grievances. Zhao Ziyang, the Premier and Deng's successor designate and top "reformer" (and liberal exponent of neo-authoritarianism ${ }^{16}$ ), told a meeting of the Asian Development Bank that the students,

\footnotetext{
${ }^{14}$ In addition to Zhao Dingxin, see Shen Tong's Almost a Revolution cited below.

${ }^{15}$ The text of the dialogue was broadcast on Beijing Television Service and is available in Oksenberg.

16 "Neo-authoritarianism" referred to the political control of the populace during the "necessary" period of social dislocation and discontent during the Dengist "reforms." What was wanted was a strong and "liberal" leader. On this issue, see Sautman, "Sirens of the Strongman" (The China Quarterly 129 March 1992: 71-102).
} 
as evidenced by their slogans ("Support Socialism!," "Uphold the Reforms," "Oppose Corruption," and the like), were "by no means opposed to our basic system" (cited in Zhao 158). Zhao also leaned on the state media to report the demonstrations more positively, which they indeed did, thus in effect reversing the infamous editorial.

These gestures towards conciliation were too little too late, and the movement escalated. Not least because it was no longer in the students' hands. On the $2^{\text {nd }}$ and $4^{\text {th }}$ of May, there were large demonstrations reaching 100,000 on the latter, commemorative date. Meanwhile, urban workers, state journalists and others began to join. In fact the moment of workers' participation - completely missed in Western fascination with the students and "anonymous" citizens - is essential and what made Tiananmen a genuinely mass movement. I will return to this neglected area below. On May $13^{\text {th }}$, two days before the next official dialogue, the first, absolutely radicalizing hunger strike commenced, with up to 2,000 students participating. Zhao conservatively suggests that the hunger strike was a mistake, marking the beginning of the decline of the movement, its disorganization and its co-optation by "radicals" such as female student leader Chai Ling; Maurice Meisner more perceptively notes that it was "a stroke of tactical political genius" that activated popular support and "politicized increasing numbers of Beijing's 10 million people" (Zhao 161-70, Meisner 427). The strike galvanized Beijing and brought the movement into sharp conflict with the regime. The historic visit of Mikhail Gorbachev had to be removed to the airport tarmac, far from Tiananmen. Three days into the hunger strike, in a sign of mass support for the movement and of the increasing tension, one million people filled Tiananmen Square.

At this point, with the encouragement of a group of fifty intellectuals, some student leaders tried to persuade others to end the strike, not least because martial law itself seemed immanent (by the $20^{\text {th }}$ the hunger strike finished). Indeed, on the evening of the $19^{\text {th }}$ PLA troops from the $38^{\text {th }}$ Army entered Beijing from the suburbs, and early the next morning Li Peng and President Yang Shangkun declared martial law. Zhao Ziyang had voted against martial law and was forced to resign. That evening he bid his tearful farewell to the hunger strikers, after pleading with them to return to their campuses. The people of the city met the arrival of a mostly unarmed people's army with barricades, effectively cutting off the army's logistics. Yet the relations between the people and the 
army were remarkably peaceful, complete with singing competitions and only occasional violence breaking out. As a result a stalemate was achieved, with the government withdrawing its troops on May $22^{\text {nd }}$. By this point numerous other student groups, many of them from well outside Beijing, also occupied the square and challenged the authority of the original hunger-strike leaders. The latter failed in persuading all students to leave the square. While many did leave, the square was re-filled by day with newly established workers' groups and other ordinary people. Two other notable arrivals, the Goddess of Democracy statue and Taiwanese rock star Hou Dejian (who performed enthusiastically) further drew people in. At this point "Tiananmen" was well and truly a mass movement.

That evening new troops advanced on the square. Details of the fighting remain somewhat obscure but what we do know now is that no deaths occurred in the square itself. The remaining students were allowed to leave, thanks in part to the intellectuals' and Hou's negotiations with the troops. The deaths occurred on the outskirts of the square, chiefly on Chang'an Avenue towards the west. The great majority of victims were workers and other "ordinary" people involved in clashes with the troops or simply in harm's way. Over 100 military vehicles were burned. The exact death toll is unknown, but has been revised downward from several thousands to several hundreds. ${ }^{17}$ Riots broke out in faraway Chengdu, a train was burned in Shanghai, and there were reports of skirmishes among troops. In the months afterwards, the government arrested many students, workers, and people alleged to have fought on the streets. There were numerous post-June $4^{\text {th }}$ executions (though I am unaware of any students killed after June 4). Others managed to flee the country. Deng appeared in public on June $9^{\text {th }}$, praising the military. Contra many China experts, the Tiananmen event triggered neither the regime's collapse nor its international ostracization; it did not usher in an era of so-called hard-line brakes on the rapidly privatizing and globalizing economy. Deng launched his famous Southern Tour in 1992, greatly escalating the pace of economic liberalization, and by 2000 China joined the World Trade Organization with permanent "most favored nation" trading status with the U.S. The Party's legitimacy was hereafter indissolubly hitched to national economic performance.

\footnotetext{
${ }^{17}$ Zhao notes the government tallies 300, including soldiers' deaths, and Timothy Brook in Quelling the People (New York: Oxford UP, 1992) has accounted for 478. But the toll may be higher, especially if we
} 


\section{Re-inscribing Tiananmen as The Still-Birth of Civil Society}

In what follows I wish to show what is left out in standard accounts like the one above and in the re-inscription whereby Tiananmen serves to signify civil society and China's becoming-normal. I will critique this Sinological coding as akin to an old-fashioned colonial discourse, and will offer alternative aspects of 1989 that complicate and displace such knowledge. This alternative information is meant to suggest a counter-knowledge of the Tiananmen event, of Chinese political forms and reality and of the present's connections to the Maoist past. As I've suggested, we can apprehend this form of orientalism in the ways that Tiananmen has been explained and constructed - what happened, why it did, and what it means for the future of China, as well as for how we understand its Maoist (or earlier) past. But what emerges from these standard analyses is the "knowledge" that China is in a world-historical process of becoming modern and generally equivalent to the West, and moreover that this must happen for it to progress, develop or become free and modern. This statement cuts across virtually all explanations, within Sinology and without, and is perhaps the paramount element within Sinological-orientalism and its global range - its global "system of dispersion" (Foucault 37).

Of the major schools of Tiananmen interpretation - the elite-factional, culturalist and civil society approaches - it is the latter which dominates, though they all overlap, often in the same analysis. ${ }^{18}$ Civil society is the subtext of the other two, in that it serves as what is missing, lacking among the elites and within Chinese culture. Thus Jonathan Unger notes: "What the urban populace of China was demanding, in short, was no less and no more than 'civil society.' When they plastered their banners with the word 'democracy,' what the word meant was not democracy in our terms but rather Civil Society" (5). Civil society is here defined (even capitalized) in the conventional liberal

include undocumented executions afterwards.

${ }^{18}$ The predominance of this approach is revealed in the number of publications on the subject. See the special issue of Modern China (19.2 April 1993) on "Public Sphere/Civil Society in China?," Baogang He's The Democratic Implications of Civil Society in China (New York: St. Martin's Press, 1997), Gordon White et al.'s In Search of Civil Society: Market Reform and Social Change in Contemporary China (Oxford: Clarendon Press, 1996), and Ding Yijiang's Chinese Democracy after Tiananmen (Vancouver: 
or Hegelian sense, as it is everywhere in China studies, as the social "space" between the political sphere (society) and the populace at large, and is constituted by non-state institutions; it further requires "an independent ethos" that Unger sees as heretofore lacking in several thousand years of Chinese history (5). ${ }^{19}$ Thus within the students' and workers' creation of "autonomous" organizations, "a new consciousness [an "independent ethos"] had been born," and yet, tragically, it was but "crudely formed" (as were their notions of democracy), and so the Chinese have "a great many more steps" to go before they reach the undefined promised land (Unger 5, 7). So, too, the eminent social theorist Craig Calhoun will proclaim that what the students truly desired, and what the event itself marks, was the emergence of a "public sphere" and civil society within the PRC. It is as if the bourgeois narrative of political and economic "development" were truly universal, and as if we know what "civil society" and "public sphere" truly are in the West let alone in the context of, say, contemporary China. Hence: "Student protest was shaped by the emergence of a civil society in which citizens were linked outside the direct control of the state and of a public sphere not restricted to intellectuals" (Calhoun 22). Moreover, the movement failed on account of China's long-standing, "totalitarian" negation of the private, familial sphere, and of the space for "rational-critical discourse" (Calhoun 22, 95). Indeed Calhoun will outdo Unger in finding what has always been lacking within the Chinese character and society, but which started to emerge in the student movement and help drive it on: friendship. Due to cultural difference (a higher value placed on group membership than individuality), and past deformations inflicted by class struggles and class categories (the state), the "novel factor" of "ideals of friendship" only now emerged in 1989 (Calhoun 170, 171). Calhoun does not define friendship here, but uses it in the sense of "personal ties" and "individual" feeling. Thus rather than, say, allowing his notion of friendship to be challenged by the Chinese context, or viewing Chinese culture in terms other than lack, Calhoun assumes that Chinese people have always been socially controlled by the state and friendless. So strong is his desire to code the Tiananmen event as an emergence of civil society and a public sphere (with the

UBC Press, 2001), among others.

${ }^{19}$ An implicit but central assumption, for Unger as for others, is that the economic sphere - i.e., the capitalist market system - is both a precondition for the development of civil society and is incorporated within it, in the form of "independent" (non-state) unions and other activities. It is only the Marxist view 
requisite "independent ethos" and "personal friendship networks") that the very psychology, culture and character of his objects of study must be typified and fit into the model, into what he and the Sinologists see as the world-historical process of democratization.

The coding of Tiananmen as the truth of civil society entails a striking culturalism, pointing out what has always been lacking within Chinese culture, and a universalizing, untroubled application of concepts rooted in Western history to a docile Chinese reality. It also denies agency to Chinese people, who are seen as not just controlled but dominated by the despotic, totalitarian, and pre-modern state. These benchmarks of orientalist practice inform many of the analyses of Tiananmen in the influential collection, Popular Protest and Political Culture in Modern China. Elizabeth Perry, for example, refers to the "frailty" of civil society in China, as the "omnipresence" of the state has "inhibited" its "fluorescence" ("Casting" 78, 87). The protests of 1989 were doomed as much by Chinese culture as by the state's power itself. The state has, as ever, deformed the culture: the students "traditionalism" explains their - failed, non-modern - "stress on moralism" and feudal "style of remonstrance" (petitions and posters) and their "state-centric tendencies" (asking that their demands be recognized, their "deference to state authority"); all in all, the student movement was "remarkably Confucian" $(86,79,88)$. Perry does note the alleged "traditionalism" of the students was "not due to some immutable Confucian culture," but was rather the result of the age-old "state links between state and scholar." But blaming the "Confucian" state instead of "Confucian culture" is not much of an advance from the conventionally orientalist trope of using Confucianism to explain modern China. It also elides the work of scholars such as Vivienne Shue, who have argued persuasively that the Chinese Communist state is, or was, much less controlling than heretofore recognized by Sinology. ${ }^{20}$ Shue argues that Deng's "webs of commerce," having replaced the "honeycomb polity" of the Mao era, actually result in greater state control and dominance, an analysis which could have provided fodder for Perry. Perry, however, marks no differences in the regimes, vis-à-vis the state.

\footnotetext{
that sees the economic sphere as antagonistic, not merely symbiotic to civil and political society.

${ }^{20}$ Vivienne Shue, The Reach of the State: Sketches of the Chinese Body Politic (Stanford: Stanford UP,
} 
This same lack of ascribed agency and surfeit of state power - always constructed as a uniquely Chinese problem - informs the volume's analysis by Joseph Esherick and Jeffrey Wasserstrom. After noting that with the advent of the PRC "the budding sprouts of republican civil society were cut off altogether," and so again implying the telos of bourgeois modernization, or Europe, they sum up their analysis of Tiananmen as a type of staged "theatre" and proclaim: "Without a civil society, only street theatre remains as a mode of political expression" ("Acting" 59). They begin by claiming that the Tiananmen protests cannot be labeled a "democracy movement" (for minzhu or "people rule" unfortunately had "various contours of meaning"); they then code the movement and all of modern Chinese politics as a form of "political theatre," full of rituals and "symbol-laden performances" to move "audiences" ("Acting" 36). My point is not that this trope is beyond the pale, but that it should be marked as such, as a trope. It is also one that would be more effective if it were properly theorized, drawing perhaps on the work of Erving Goffman on the "dramaturgy" of self-presentation, or moreover of relevant Chinese theory. ${ }^{21}$ In Esherick and Wasserstrom's essays, the modern Chinese polity really is a stage, and all its people merely players. It is as if the complex human and political reality of one event of 1989 , let alone the previous eight decades, was simply some grand Chinese opera, nothing more. It is a trivializing analysis at best, and at worst an exoticizing one in its reduction of China to the merely cultural. The thrust of the theatre-trope is to show the lack of civil society, which is the point of their essay's comparison of China to the "successful" Eastern European revolutions. The irony of this comparison is especially striking given the comparison of the former bloc to China today. Pointing again to a lack at the heart of China, namely, the absence of Western public sphere institutions like the Church and "the culture of civil society" more generally, the Chinese are bereft. They are left with "street theatre" and rituals (a fascinating, spectacular, Hollywood-trumping but pre-modern and limited stage) (“Acting” 58). Needless to say, this fetishization of rituals and "surfaces" itself has a long history within

1988).

${ }^{21}$ The authors do briefly reference Clifford Geertz's work on Bali, and do note Chinese theatre terms, though none of this advances their analysis. The authors also show no recognition that Geertz's work has often been taken to task for its alleged ethnocentrism. See for example, Mark Woodward's Islam in Java (Association for Asian Studies Monograph Series: University of Arizona Press, 1989) and Andrew Gordon, "The poverty of involution" (Journal of Contemporary Asia. 22.4 (1992): 490-513). 
writings of the East, ranging from Mateo Ricci and Marco Polo up to Roland Barthes's Empire of Signs.

Other reinscriptions of Tiananmen as the truth of Western civil society are less culturalist, but even here the point of the concept-model is not just to criticize the regime, but to show China as only slowly, begrudgingly entering modernity, and to show its deviation from the proper telos of progress and the modern. Thus Andrew Nathan will remark: "China is finally joining the world - economically, culturally, and politically. It will, eventually, become a democracy" (Transition 77). Nathan's and others' positioning of China as not - until recently - part of the world is of a piece with classical orientalist fantasies about Shangri-La (the West's Tibet), but the more salient point is that it denies not only Chinese history - for even the Maoist de-linked "autarky" was fully a part of the world system of trade, politics and culture - but also the coeval nature of "Chinese" or real, shared time and space. ${ }^{22}$ Ralph Litzinger nicely summarizes the problem here:

European colonial anthropology tended to construct non-European others as objects of lack. These others, variously labeled the primitive, the nonliterate, and the underdeveloped, were seen to be outside the space and time of Western modernity; they were essentially denied any sense of shared contemporaneity. Culture, in both colonial and early modernist anthropology, was thus almost always situated in the realm of custom, festival, and ritual, all of which were seen to be outside the historical problematic of Western modernity ("Theorizing" 44).

While Nathan believes China will become a democracy someday (and it is obvious to him that neither the Cultural Revolution nor the "New Democracy" period up through the 50s were in any sense democratic), he does take issue with Tony Saich and others who hail the "new class of small-scale individual entrepreneurs spawned by the reforms" as proof of a civil society in 1989 (Transition 79). For Nathan, this "class" lacked the requisite "level of coherence and social autonomy" that the term - again assumed to stand for a real thing that originated in the West - implies, once again indexing the "crudely formed" consciousness and actors Unger attributes to Tiananmen (Transition 79). But to say that

\footnotetext{
${ }^{22}$ We owe the critique of anthropological discourse's denial of contemporaneity to Johannes Fabian, in his Time and the Other: How Anthropology Makes Its Object (New York: Columbia University Press, 1983).
} 
the "proper" consciousness and polity was inchoate is still to say that the Chinese are nonetheless in a process of becoming-the-same. Thus it is the figure of lack that paradoxically underwrites the logic of equivalence, of a becoming-sameness, that is the basis of the new orientalism.

But whether conceived as entirely lacking, circumscribed or nascent, Western civil society is in these analyses rarely if ever contrasted to indigenous discussions of an historically Chinese version of, or alternative to, civil society and the public. Wang Hui has for example argued that in China the public sphere has for a long time existed "within the state's space" and so cannot be a "“natural deterrent" to state power (China's New Order 179-80). Wang's point, shared by Zhang Xudong and others, is that democratic reform in China will necessarily have to work within and against the state and also against the market. ${ }^{23}$ While one would have virtually no sense of this from the Sinological accounts which refuse to engage them, the questions of civil society and public sphere were the subject of intense debate within China in the 1980s as part of the cultural fever era. While Haun Saussy's judgment that these debates were "vitiated" by their use as another thing China lacked (a civil society) seems correct, other analyses very productively recast the entire question of public sphere and democracy within actually existing Chinese history. In addition to Wang and Zhang, Liu Kang has argued that both the Maoist practice of cultural revolution and Hu Feng's theory of multiple "cultural centers" for China show the existence of Chinese alternatives to bourgeois modernity and its attendant civil society ("Hegemony" 83-4). Given what Kang aptly characterizes as "the liberal/totalitarian or anti-Marxist/Marxist dichotomies" that filter Sinological knowledge, the China field's hostility to Chinese Marxism comes as no surprise (82). Perhaps more surprising is the degree of positional superiority, the thoroughly consistent failure - among Chinese-fluent academics no less - to consult "native" sources that might challenge their reigning if also tacit assumptions. Kang's pair of dichotomies also alert us to the deep connections, especially in the case of China and Asia, between orientalism and anti-communism. Post-Mao Sinologists can work with such vulgar and uninterrogated notions of the Chinese Other precisely because their object of critique is not the Chinese people in general (whom they nonetheless often disparage by

\footnotetext{
${ }^{23}$ See Zhang Xudong, footnote 10 above.
} 
implication) but the Chinese state, or the Chinese polity and Chinese Marxism. They are part of the long history of orientalizing communists - from well before Wittfogel's branding of Stalin and Soviet Russia as "Asiatic" in the 1930s (e.g. Lothrop Stoddard's 1920 The Rising Tide of Color).

Just as important, there were many things on the ground in Beijing that directly challenge the civil society interpretation. Foremost among these were the emergence, as early as April $22^{\text {nd }}$, of the Beijing Workers Autonomous Federation and its perhaps 20,000 strong membership, and the de facto general strike emerging across the city by the beginning of June. ${ }^{24}$ Clearly, Deng et al. saw this as a most significant development: hence the "discrepancy" in whom was killed and arrested, and the speed of Martial Law and the crackdown in the first place. For while the students could win the hearts and minds of global and local observers, particularly of Americans who saw "their" symbols being displayed, only the workers could pose a real threat to their Communist Party and its economy as such. While a few Sinologists have examined the formation of the BWAF and the role of workers in the movement, ${ }^{25}$ to date no one has allowed this to recast the question of civil society as the truth of Tiananmen, or of China's past and future tout court. This, despite the fact that it is precisely the figure and place of the working class within European, if not global, history and theory that gives the lie to civil society and the public sphere as the realm of freedom and democratization. Recall that for Marx, writing from the standpoint of the proletariat, the historical emergence of the bourgeois epoch and the attendant emergence of formal equality and civil society entailed one step forward, two steps back. ${ }^{26}$ For these only emerged once labor-power became a

\footnotetext{
${ }^{24}$ The figure of 20,000 registered members comes from Ching Kwan Lee, "Pathways of Labor Insurgency," (Chinese Society: Change, Conflict and Resistance. Ed. Mark Selden and Elizabeth Perry. New York: Routledge, 2000.41-61) 56. Calhoun, however, refers to 5,000 members. I refer to a de facto general strike because while the BWAF's repeated calls for an official strike, from April through June $3^{\text {rd }}$ did not materialize, by June $4^{\text {th }}$ production in Beijing, and to a lesser extent elsewhere in China was severely affected by the amount of people - primarily workers and ordinary citizens - in the square or joining the BWAF or other workers federations. For more detail, see Ching as well as Walder and Gong. ${ }^{25}$ In addition to Walder and Gong discussed below see Wang Shaoguang, "From a Pillar of Continuity to a Force for Change: Chinese Workers in the Movement" in Chinese Democracy and the Crisis of 1989: Chinese and American Reflections (ed. Roger V. Des Forges, Luo Ning, and Wu Yen-bo, Albany: SUNY Press, 1993). Lu Ping's collection of documents, interviews, and analyses about the BWAF in The Moment of Truth are invaluable.

${ }^{26}$ Marx's most searching treatment of these and related questions, his "social theory," is to be found in volume 1 of Capital, particularly Chapter 1 and the "Appendix: Results of the Immediate Process of Production" (Trans. Ben Fowkes, New York: Vintage Books, 1977). See also "On the Jewish Question"
} 
commodity and all concrete labor reduced to abstract, homogenous labor. This is to say, then, that civil society is predicated upon the capitalist class system, and that formal political and civil rights - as valuable as they can be - cannot result in social emancipation for the working class. For the latter would entail means of redress well beyond civil society, straight down to the labor process in the fields and factories and to the state administration of the economy. "Freedom and democracy," the alleged raison d'etre of civil society, thus appear as very much the empty signifiers they are, capable of being articulated within civil society to anything but the economic as such, at least for the great majority of laborers in China who spend the great majority of their time working and reproducing their labor-power.

Now one could argue in the traditional liberal way that the state can be made to bend if not break in response to civil society, such that class bifurcation can be redressed if not transcended by the politics of the public sphere. But this perspective, whatever sense it made in the 1960 s of the West, still presumes that civil society is independent of and ultimately stronger than the state. And it is precisely these two historical grounds and requirements that have been disputed by political theorists and historians as diverse as Sheldon Wolin and Antonio Negri and Michael Hardt. ${ }^{27}$ Drawing on a genealogy of "postmodern" and American "communitarian" thought, Hardt and Negri argue that at this point in history, the state has subsumed civil society and is able to "legitimate autonomously the new social order," with class and other divisions intact (Labor 308). Or more specifically, capital has not only instrumentalized the state but now the latter "shows a level of structural integration of civil society that nears the extreme foreseeable limits." In sum, "civil society no longer exists," as the state no longer needs it to deal with social antagonisms or to "legitimate its rule" (Labor 146, 261). ${ }^{28}$

This theoretical and historical subsumption of civil society raises many questions in relation to the Chinese context. At one level it suggests that it is the U.S.-West that is following the Chinese path, rather than the other way around. But here I simply want to claim that Hardt and Negri's point, as well as the range of studies they draw on, call into

and "Critique of Hegel's Doctrine of the State," collected in Early Writings with a brilliant introduction by Lucio Colletti (Trans. Rodney Livingstone and Gregor Benton. London: Penguin, 1974).

${ }^{27}$ Sheldon S. Wolin, The Presence of the Past (Baltimore: Johns Hopkins UP, 1989.)

${ }^{28}$ The point of the genealogy is to show an unacknowledged but common consensus on the eclipse of civil 
question the applicability of the civil society model as applied to China. The implication is that the approach is anachronistic. Additionally, the global argument about the subsumption of civil society by the state dovetails with Marc Blecher's analysis of contemporary state-society relations in China. Blecher argues that while the Tiananmen protests suggest that "society" has in the Deng era achieved some autonomy from the state, the dialectical flip side of this is that "the state has also been acquiring new types of autonomy from civil society" (144). While this assumes that some unspecified form of civil society "fits" China, the larger point is that the state seems poised to simply ignore civil agitation. It can say that this imputed civil society no longer exists. And regardless of one's specific theorization of the matter, "civil society" is an unlikely vehicle for the political "liberalization" of the Chinese state that China studies, like the broader Western culture of which it is a part, so strongly desires.

\section{Un-Civility, Sinological Anxiety, and a Worker's Tiananmen}

But to return to the BWAF and workers' involvement in the Tiananmen protests, one can see how problematic it is to insert their demands and activities into a budding (or missing) civil society. For their demands were by and large for anything but their allotted, modest place within such a sphere:

The working class is the vanguard of the People's Republic. We have every right to expel dictators. . . . With a great, concerted effort, we fight bravely to uphold the truth of Marx, Engels, Lenin and Mao, and to overthrow the dictatorship of the aggressors Deng and Zhao. We will make them repay the ten-year debt of blood and tears $\left(\mathrm{Lu} \mathrm{188,215).}{ }^{29}\right.$

What is clear from these and similar statements (from dazibao or big-character posters) is not just their Marxist (indeed Marxist-Leninist-Maoist) rhetoric, but that the perspective and implied author embodied within them flies in the face of a merely civil, "independent

society. Their widely debated Empire repeats much of this analysis in less developed form.

${ }^{29}$ The first quote is from "The Workers Manifesto" of the BWAF, which genre also helps explain the Marxist rhetoric, and the latter is from "Psalm to the Beijing People" by "a Chinese Worker." 
ethos" that recognizes all "citizens" as equivalent in a "culture of civil society," one unmarred by such unfortunate traits as class hatred and resentment (to recall Calhoun's characterization of the Mao era). As another poster put it, their class is the vanguard precisely because "Wealth, created by our labour, is used to maintain the lifestyle of those overlords sitting on the backs of the people," and so their class has "a historical mission and a sacred duty" ( $\mathrm{Lu} 226){ }^{30}$ As with the above, this "uncivil" statement authored by "A Union staff member and 253 Workers" refuses any notion that the working class is simply one player among others in the game of civil society. Their standpoint recalls not just Lenin but Mao, and the decades-long positioning and privileging of workers - not least through trade union education and propaganda - as the leading class of the revolution and nation-state. But it also recalls Georg Lukács' classic work on reification and class consciousness, which theorized how the proletariat, because of its historical positioning within the process of production, is uniquely able to see (totalize) the social totality and to lead to its transformation. ${ }^{31}$ But Lukács' argument is larger than this, and related to the problematic of civil society in his justly famous dissection of the antinomies of bourgeois thought. From a Lukácsian perspective, the working class simply elides such antinomies as civil society, a sphere of freedom predicated upon class division and part and parcel of the anarchy and social differentiation that makes the totality so difficult to apprehend. Put another way, if an antinomy is an irresolvable contradiction between an idea of reason and a concept or fact of experience, then from the standpoint of the working class civil society is an antinomy - a lie - in itself.

What is also clear is that the workers and the BWAF rejected liberal rights discourse (a hallmark of the civil society model), and the myth that the Dengist reform era was all to the good. In fact not only Deng (who the students avoided criticizing) but the liberal 'reformer' Zhao Ziyang, so admired by some students and intellectuals, are held responsible for the "ten-year debt of blood and tears." In fact, Zhao's penchant for golf was mocked by one early BWAF poster: "Mr. and Mrs. Zhao Ziyang play golf

\footnotetext{
${ }^{30}$ This document dates from May 20, the moment of martial law, and is entitled, "The Working Class Will Not Stand By Indifferently."

${ }^{31}$ Georg Lukács, "Reification and the Consciousness of the Proletariat." History and Class Consciousness: Studies in Marxist Dialectics. Trans. Rodney Livingstone. Cambridge, MA: MIT Press, 1971. 83-222.
} 
every week. Who pays the green fees, and other expenses?" (Lu 184). ${ }^{32}$ The workers' rejection and deconstruction of the liberal/civil notion of rights can be seen in their texts. Rather than simply claiming, like the students, the right to have their demands recognized and addressed by the regime, they insist on the right to "expel dictators," very much a rejection of the right to mediation through civil society. Moreover, they refuse the right to self-preservation. As a worker's poem entitled "Fast Letter" put it:

If the death of one or more / enables many to live better / and the motherland to prosper /

then we have no right to drag out an ignoble existence ( $\mathrm{Lu} 227$ ).

The extra length of the last line, following the shorter, qualifying and prefatory first three lines, endows the rejection of "right" with an especial force. ${ }^{33}$ It is a rejection of right as such, for no right is more basic than that of self-preservation. The brief workers' statements above have certainly shown their anger and Marxist orientation, but what is remarkable in this short poem, beyond its compression of a complex thought into so few lines, is the final "ignoble existence." It is here where we feel the tragedy of the great reversal, the shift from a regime which took the working class and peasants as its summum bonum, and had inscribed the nobility of labor, the fundamental value of workers, and proletarian militancy into all of its major institutions, from the arts to the constitution itself. For even if one takes a dim view of Maoist and immediately post-Maoist regime practice (and this would be decidedly one-sided), no one can dispute that urban and rural labor and laborers were indeed endowed with a nobility and special status, unmatched even by the Soviet Union. ${ }^{34}$ So the poet's reference to a worker's now "ignoble" life carries with it not just a flash of historical insight - the Dengist "revolution" was for many a counter- one - but a felt sense of what it means to go from

[1923]

${ }^{32}$ This dazibao was entitled, "Ten Questions for the Chinese Communist Party."

${ }^{33} \mathrm{I}$ am thus assuming that this line-length argument holds true for the Chinese version of the poem. I have not been able to locate the original version.

${ }^{34}$ For even Stakhanovism was a comparatively short-lived affair, though there is no doubt it was a popular cultural fever for awhile, not just a strategy of the Stalinist state. 
the noble, symbolic vanguard to one of the powerless. It clearly is a "citizen" uninterested in the game of civil society and negotiation with the state. That option seems unavailable (given the class position of poet and addressee), and in this poem as with other workers' statements, there is not the students' oft-noted demand for individual recognition and approval, nor an "independent ethos." Those decades of proletarian valorization in China, and the special status of laborers, do not just go away with the Dengist attacks on same. For the worker in this poem still sees him or herself - and his or her class - as having the crucial role to play: only with their ultimate struggle, to the point of death if need be, will the "many" "live better" and the "motherland" "prosper." Indeed this "fast letter" is very much addressed to a collective destination: in place of the first-person "I" seen so often in the students' character-posters ("I have a dream. / For this dream I'm willing for my blood to be shed"), or their familial rhetoric ("Mama, we're not wrong"), here there is a pointed "we" (Han 319, 127). ${ }^{35}$ And the logic of the poem's "sentence" - the movement from "If" to "then" - can be seen as an intersubjective hailing of the revolutionary working class, the proletariat as such. What this poem indexes, in sum, is not an emergent civil or independent discourse, but a return of working class militancy, and in place of reform and dialogue: angry, red revolution. It is this incivility, and the workers' militant and Marxist discourse in general that helps give the lie to the civil society coding. From the perspective of the workers in the Square and the BWAF, the relevant problematic of Chinese politics and protest is not civil and "normal" agitation and redress, but leftist revolution. Notwithstanding the massive and institutional de-Maoification of the 1980s, here too we see the legacy of the Mao era in Tiananmen, $1989 .{ }^{36}$ I return to these points in what follows.

And yet Andrew Walder and Gong Xiaoxia have, for their part, coded the BWAF and the workers themselves in terms of the conventional civil society model, in this case

\footnotetext{
${ }^{35}$ The poem "Mama, We're Not Wrong" is by Ye Fu and dates from May 1. But as the editors note, this phrase appeared early on in the movement ( 9 April). This poem likewise uses the first-person and calls for personal recognition and approval. "I Have A Dream" by Jie Fu was posted at Nanjing University on May 21. At the risk of being ungenerous, it is striking to compare Jie's use of Martin Luther King's line (assuming this is intended), to King's own, famous universal appeal. Whereas the author brings this line back to himself, King's address hails a collective entity of all Americans.

${ }^{36}$ The influential yet deeply problematic if not racist documentary on Tiananmen by Carma Hinton and Richard Gordon (with screen-writing credit to Geremie Barme among others), The Gate of Heavenly Peace (1995) also connects the protest movement to Mao but in a purely negative and Fu Manchu-esque like way. I critique this film as the first China studies movie in a work in progress.
} 
via the Polish Solidarnos labor movement. While initially critical of the BWAF (and the protests as a whole) for not being as active as Solidarnos, they come to see the Beijing federation as more akin to its 'natural' analogue in Gdansk and the requisite "unabashed working-class trade-union mentality" ("Workers" 4). Thus Tiananmen and the BWAF are evaluated on the basis of an ideal type: a populism and trade-unionism that is anti-communist and "democratic" as opposed to "socialist." Thus any reservation about using conventional liberal and Western models is only about how well China and its workers measure up, not about how they might challenge, let alone displace such knowledge itself. This is, in other words, another instance of the strategy of positional superiority.

This technique is further revealed when Walder and Gong damn the 1989 workers with faint praise. Thus they refer to the 1989 workers as "sharp" but "quite ordinary working people ... with limited education and writing ability (as their wall-posters and handbills make evident)" (4). Now the first thing that strikes one about this description is that it in fact negates the creativity and extraordinary quality of much of the writing in the BWAF's posters. Take the following statement from "Ten Strange Aspects of the Current Situation": "5. There are a lot of stylish new hotels. A crane standing among chickens catches the wind. Houses for the people are insufficient. Slow is the intake of valuable experience; yet the toilet attendants learn quickly to charge money" (Lu 199). Here the author begins with an aspect of the Beijing city-scape in the "reform" era that is so often noted by Sinologists and foreign correspondents as the most obvious sign of the wisdom and success of the Dengist "revolution" - the explosion of skyscrapers and new construction as places of multinational (or joint-owned) business and tourism. But as if in direct, dialogic response to this Sinological point of view, a response that internalizes the other's discourse and re-articulates it, the author upends it and turns the skyscrapers into a sign of the great reversal. The author invokes the people's perspective (and their lack of housing) and in so doing demystifies the "obvious" meaning of the hotels and new cityscape. What the hotels signify is nothing less than the Dengist betrayal of socialism and the Party's mandate to "serve the people." As with the "fast letter," this poster indirectly but powerfully documents the degradation of labor and the status of the working class as symbolic vanguard of the "ongoing" revolution, here by invoking the 
most menial, degrading type of labor to say, here is what workers are today, mere janitors who have to charge a little extra money just to get by.

But the statement also ambivalently characterizes the worker's action of charging money to clean the toilet. It is poignant and shameful, yet perfectly reasonable and natural, and merely shows the workers doing what everyone else is - practicing capitalism. Moreover, by closing this brief but complex analysis with the figure of the entrepreneurial janitor, the author thereby comments upon and again debunks the bit of official and intellectual discourse which precedes it. For the awkward "intake of valuable experience" can only refer to the regime's own legitimation of the problems and social costs of neo-liberal privatization - that the regime and putatively Chinese society as a whole is inevitably and simply going through a learning curve in the great, historical process of modernization. Thus according to official discourse the social costs of "reform," from the smashing of the iron rice bowl of social security to massive unemployment, are all unfortunate but inevitable and temporary problems in the modernization process. For the so-called "ordinary" author, then, this cerebral, officious discourse is invoked, but only to be mocked as so much useless verbiage. What modernization and its legitimation amount to: a toilet attendant charging a bit on the side.

Finally, note the central conceit of the poem that drives the argument and makes it so memorable: the remarkable metaphor, embodied in an old colloquialism, that makes the new hotels in a city full of unemployment and lacking in affordable housing akin to a crane standing among chickens. For the distant bird's-eye view of the "crane" leaves out all the telling detail and is blind to ground-level reality. So too there is a clever pun on "crane" as bird and as construction vehicle. Thus rather than indexing a lack of education and writing ability, this rigorously ironic statement is indeed sharp in both content and form, and poetic in its compact, dense expression of a complex thought and range of feeling within a very few words.

So much then for at least part of the lack that Walder and Gong attribute to the workers themselves. But they see this as an advantage for the development of civil society and democracy in China. They favorably contrast the "ordinariness" and lack of education of the BWAF members, with the "relatively literate" workers' protests and writings from the Cultural Revolution decade, the great majority of which were radically 
socialist and Maoist (Walder and Gong, "Workers" 4). For the latter were apparently too radical and militant altogether, whereas the BWAF was properly Polish and "trade unionist" in its "mentality and political orientation," and therefore represents a new future for Chinese democracy despite their comparative lack of literacy ("Workers" 3). And yet this new formation ends up being the rather old one of "working-class populism" and the incorporation of "ordinary citizens" and the working class within a "democratic movement" - in other words, the program of the left-wing of the U.S.A.'s Democratic Party before the mid 1980s (28). As something new and innovative, as opposed to an imposition of the Euro-American way upon a recalcitrant Chinese reality, this is pretty weak tea. As for the "populist" nature of the BWAF this may be true in a banal sense but virtually all the evidence of their actual posters and statements reveals the specifically Marxist, and often avowedly Maoist orientation of the BWAF as a whole. To be sure, not all members were radical in this sense. Han Dongfang, one of the early leaders of the BWAF and still a labor activist in Hong Kong, has ironically said he is a believer in "free" markets and not socialism. ${ }^{37}$ But even if his view were representative, this would hardly brand the BWAF as embodying a universal - i.e., Polish - "trade union consciousness," as if a consciousness could have no national characteristics (such as the Catholicism of Solidarnos.) Moreover, the weight of the evidence from 1989 suggests Han is more the exception that proves the rule of the socialist and "vanguard" orientation of the workers' protests. Thus not simply the repeated calls for a general strike, but the posters and appeals of the BWAF reveal its radical roots. Indeed, it is unsurprising that Walder, Gong and others do not cite any of the documents referred to above (even though Lu's BWAF collection appears in their notes). So too there is no reference to workers' posters like "An Official Denunciation of Deng Drafted for Marx," or "Lenin is Crying in the Nether Regions" or another BWAF poster, "Ten Questions," which mockingly asks the Party to step up and "explain the concept and meaning" of "revolution" (Ogden 87-8). ${ }^{38}$ For to cite such published, public statements would present the Sinologists with great difficulty in squaring the Solidarnos/civil society model with

\footnotetext{
${ }^{37}$ See the interview with Han, and another BWAF activist identified only as "Profile One," in Lu Ping.

${ }^{38}$ The "Denunciation ... for Marx" and "Lenin is Crying" posters can be found in Ogden et. al., 310-11 and 111. The former was published at Beijing University, and the latter in the square. "Ten Questions," from the BWAF, is in the same volume, 87-8.
} 
the workers' own, stated political orientations. ${ }^{39}$ The latter's intentions and their very self-understanding are simply not part of the Sinological equation.

Walder and Gong's method, that of conventional social science style interviews, in fact turns out to be anti-empirical and marks an attempt to have - to incite - the workers say what they want them to: that they are pro-reform and anti-communist "trade unionists." This is indicated in the following admission: "After some probing, our gongzilian [BWAF] informants admitted that despite the severe inflation of recent years, living standards had not actually declined since the Mao era for most of them" (emphasis added) (Walder and Gong, "Workers" 20). ${ }^{40}$ While their questions are not revealed to us, it is clear that for the experts, the workers have something to admit. Or even confess: that any number of real appearances to the contrary, the anti-Maoist and neo-liberal "reforms" were all to the good, and the workers are plain down-to-earth folk, not at all like the angry, militant radicals of the Mao decades. Given the visible evidence of radical militancy (the posters, the iconography, the rhetoric), Walder and Gong's analysis - as with most Sinological understandings of Tiananmen - thus stands as anti-empirical, a knowledge based on how well such statements and other signs fit into the a priori schema of civility, civil society and modernization. As Said and others have noted, orientalism itself is profoundly anti-empirical, and has "the self-containing, self-reinforcing character of a closed system" (Orientalism 70).

Walder and Gong's dismissal of the Maoist rhetoric of the BWAF's and others' posters, and of the 1970s workers, is a sign of positional superiority and the unreflexive imposition of foreign, traveling theories. But it is also perhaps an anxiety with the "Chineseness" or "Maoist" nature of the workers. Indeed how else to explain the blindness to such visible signs of old-fashioned, proletarian militancy (e.g. the frequent

\footnotetext{
${ }^{39}$ They do refer in passing to a few BWAF handbills but the bulk of their "evidence" comes from interviews with two "activists," one a small-scale entrepreneur. They also translate a document that resembles the "Ten Strange Aspects" text discussed above. But if these are identical documents, it is clear that they have radically depoliticized the BWAF text and eliminated its brutal sarcasm and irony, so as to make it pro-reform. In place of the mocking of official speech, they have the text endorsing it. Compare to Lu Ping's version.

${ }^{40}$ I leave aside here the question of whether "standards of living" have risen and how that relates to quality of life questions. This is certainly debatable for the more than 100 million unemployed laborers in China today. See also the comments from "Activist \#1" in Walder and Gong: "After the reform, we have refrigerators; but look, what are we going to put in them? ... And the refrigerators are bought with loans anyway" (20).
} 
rounds of "The Internationale"), of the specter of Mao and communism? This is not to say that the whole Tiananmen event was simply a "Maoist" or working class movement, nor that there is some essence to "Chineseness." But there are certainly deeply held notions of the latter, and among foreign observers at least, one of these has been that of the "fundamentalist" and menacing Maoist "Red Chinese." It is this figure that haunts Walder's desire to make interviewees - constructed as anthropological objects - speak against such an identity. They must reduce the writings and activities of the workers to an interpretation that makes them fit within a "normal" or universal pattern of "democratic" protest, trade unionism and modern "development." Even militant, proletarianized strikers must become-the-same.

A full analysis of the parallels between the Mao era and the 1989 movement is beyond the scope of the present essay. But given the orientalist re-coding of 1989 as a (failed) break with that era, some remarks are necessary. The essential point here is that the 1989 event was not in fact a break, but rather conditioned by the mass democracy of the Mao years and the Cultural Revolution. As noted, the most visible signs of this range from Maoist iconography to rhetoric (red books, badges, portraits, slogans, demands). While the BWAF posters speak for themselves in this regard, equally striking is the popularity among students of Mao's Cultural Revolution slogans about Red Guard youth. As student leader Shen Tong has recalled, referring to a march he led, megaphone in hand: "I walked up and down alongside the marchers, encouraging them by calling out some of Mao's sayings. ... 'Those who put down student movements have a bleak future' and 'If the students don't act, who will?' - slogans that seemed perfect for us now" (Almost 180). This is not to say that Tiananmen was simply the continuation of the CR. Some students and virtually all the intellectuals explicitly contrasted their "pure," patriotic movement from that of the Red Guards. This is to be expected given past Maoist "punishments" of the intellectual class and the de-Maoification. But the complex, paradoxical relationship between Tiananmen, Maoism and the CR - as evinced by the iconography and rhetoric - do indeed speak to a larger history, or more specifically to a certain Marxist or revolutionary construction of this that remains available even decades after $1989 .^{41}$

${ }^{41}$ In a recent article, Calhoun and Wasserstrom address the relations between Tiananmen and the CR, but 
Here we need to return to Zhang Xudong's point about the CR being China's largest, singular form of mass democracy. This point acknowledges the violence, chaos and ultimate failure of the $\mathrm{CR}$, but also targets the reification of Western, procedural democracy as the one true type. It posits instead the history of China in the last century and emphasizes the mass and participatory aspects of "democracy." From here, one can indeed see Tiananmen as in part a legacy of the Mao era, and the return of the CR's massive, actualized "right to rebel." The point here is not just that the form of Tiananmen, qua protest, owes much to the CR (the rhetoric, the enormous mobilization, the anger over corruption and bureaucracy). It is also part of the history of democratic or popular struggle since 1949 that was against the state bureaucracy and Maoist in inspiration. In short, in telling the history of democracy in China as a failed but inevitable struggle against a feudal and then one-Party state, of which Tiananmen is just one more failed example, Sinological-orientalism elides the fact that Mao and his followers were also attempting to democratize the state and society he and they created. To be sure a multi-party voting system was never an option, for historical and ideological reasons (the Cold War and the "dictatorship of the proletariat") as well as the quintessentially Maoist passion for a politics and democracy of commitment, mobilization and participation above all else. That most Westerners do not share these beliefs, or that we can see the relative importance of the vote, does not mean there was no democracy or rational political theory in China. Thus Lin Chun, herself at times a critic of the Maoist state as a form of "patriarchal socialism," notes that "the short-lived experiments encouraged by Mao in workers' participation and workplace democracy were truly valuable" even though they did not last ("China Today" 39). And one reason they did not last was the turn to the right after Mao's death.

The essential point here, for our purposes, is that under Mao there were actually existing attempts at a greater worker's democracy. The most famous example of this remains the short-lived Shanghai Commune of 1967 but one should also include the formation, over a period of eighteen months, of mass organizations (such as the workers

in an almost wholly negative and symptomatic way. In this their views are close to the more conservative of the student leaders as well as the CCP's own condemnation of the CR as one long trauma; and civil society remains the implicit yardstick to measure both events. "Legacies of Radicalism: China's Cultural Revolution and the Democracy Movement of 1989," Thesis Eleven, May 1999: 33-52. 
management groups documented by Charles Bettleheim ${ }^{42}$ ) and provincial "revolutionary committees" that were to transform the existing Party structure (Gray, Rebellions 352-6). These organizations and committees included workers and allowed them a political voice within their workplaces and communes. So, too, one should recall that it was during the CR that Mao and the left pushed for the right to strike in the constitution (a right later rescinded in 1980), in direct response to the strikes that erupted from time to time during the CR decade, especially in the 1970s. In short, as Maurice Meisner has noted, "the Cultural Revolution politically activated China's urban working class for the first time since the proletariat had been so brutally crushed by Chiang Kai-shek's armies in 1927" (Mao's China 311). These struggles for a greater worker's democracy ultimately failed because of Mao's and the left's inability to institutionalize their programs and gains, and because the CR was forcibly brought to an end by Hua Guofeng and Deng.

This failure - a noble failure - should not blind us to the history of this struggle, or to its connections and influences on Tiananmen, including its status as a decades-long process of political education for the workers of Tiananmen and even today. This aspect of Chinese and especially workers' historical political culture militates against the Sinological coding of Tiananmen as a failed yet inevitable moment in China's becoming the same as "us" through a universal narrative of "normal," "civil" democratization. So too it offers a counter explanation for the so-called "nostalgia" that workers and some students felt for the leadership and society of the Mao era. This is partly explained by the previous decades of revolutionary culture and proletarian or Marxist education, including the more beneficial aspects of the Cultural Revolution (rural health, education and development programs, agitation for women's equality beyond labor-force enrollment). Put another way, the decades-long struggles for a new, radically egalitarian order, as well as still influential symbols and mythemes like "the Yan' an way" persist even some twenty years after Tiananmen. And they persist despite, or perhaps because of, the Dengist "some must get rich first" propaganda and the influence of consumerism and neo-liberalism in China.

The so-called nostalgia for the Mao era - for the revolutionary passion, ideals and

\footnotetext{
${ }^{42}$ See Bettleheim, Cultural Revolution and Industrial Organization in China (Trans. Alfred Ehrenfeld. New
} 
lack of corruption in the old Party-state - is further explained by the return of massive economic inequalities and exploitation already well under way by 1989 during Deng's capitalist revolution from above and of a "highly elitist school system" that in effect bars the working class (Meisner, Deng Era 345). For the economic injustices that were already evident in 1989 have only grown worse in the ensuing decades. Thus when Walder and Gong make a point of steering away their interviewees from proclaiming that even economically things were better in the Mao era, they miss the point that such nostalgia is not some fantasy, some mere yearning for a Golden Age or an instance of residual brainwashing. It is rather a rational, ethical and yet passionately political response to real conditions of existence, and one based on historical circumstances inherited from the Mao era, as opposed to the ideal type of political protest as it exists in the heads of China experts.

As with 1989, there is no doubt that Mao's imprint looms large even today, that among peasants, urban workers and even some intellectuals, Mao is still seen quite positively, the efforts of Sinology, liberal "reformers," and the Party leadership itself notwithstanding. ${ }^{43}$ This is a dimension of Chinese political and popular culture that Sinology, and the West more generally, have yet to deal with, much preferring - needing - to see Mao as either a totalitarian monster just like Stalin, or as a depraved despot (as in numerous "tell-all" biographies). ${ }^{44}$ In short, given the "received wisdom" that constructs Maoism as totalitarianism or "oriental despotism" (and these are synonymous in the present context) a crucial bit of knowledge for shoring up the capitalist West's self-constitution as the very epiphany of reason, freedom and democracy, it is no accident that the specters of Mao and communism need to be exorcized. It is this dynamic, rooted in both fantasy and knowledge production, that results in statements like Barme's "Mao bin Laden or is it Osama Zedong?" or Nathan's dehumanizing summation of the collectivist era: "Mao's people complied out of patriotism, a sense of unworthiness, faith in a despot's wisdom, and because they preferred to be among the victimizers than among

York: Monthly Review Press, 1974).

43 "Mass incidents" over social justice issues often contain Mao portraits or slogans as a way to remind the state of its (past) obligations. Barme's Shades of Mao while full of his own snide commentary, usefully details the chairman's complex life after death. See also Han Dongping, The Unknown Cultural Revolution (New York: Garland, 2000).

${ }^{44}$ For a critique of such pulp-orientalist texts, see Gao Mobo, The Battle for China's Past (London: Pluto 
the victims" (Nathan, "Epilogue" 215). ${ }^{45}$ While written before the recent war on Iraq, such statements - betraying not just colonial arrogance but anxieties about "terrorism" and fundamentalism in the pax Americana - underscore the fact that orientalism and positional superiority continue to constitute the identity of the U.S-West. With this in mind, it is no accident that the civil society and "democratic" modernization template are dominant within the China field, as today that template and American culture remain deeply informed by a Cold War triumphalism and a mythic exceptionalism that the rest of the world must somehow follow.

Press, 2008).

${ }^{45}$ Geremie Barme, "Over 30 Years of China and Australia." Asialink Seminar Series. Nov. 2002. 


\section{Works Cited}

Barme, Geremie. "Over 30 years of China and Australia: some thoughts on a glum convergence.” Asialink Seminar Series. Nov. 2002. 15 June 2008. $<$ http://www.asialink.unimelb.edu.au/archived/events/past/past_events_public/ov er_30_years_of_china_and_australia-some_thoughts_on_a_glum_convergence>.

Blecher, Marc. "The contradictions of grass-roots participation and undemocratic statism in Maoist China and their fate." Contemporary Chinese Politics in Historical Perspective, Ed. Brantly Womack. New York: Cambridge UP, 1991. 129-52.

Calhoun, Craig. Neither Gods Nor Emperors: Students and the Struggle for Democracy in China. Berkeley: UCP, 1994.

Dirlik, Arif and Maurice Meisner. "Politics, Scholarship, and Chinese Socialism." Marxism and the Chinese Experience. Ed. Dirlik and Meisner. New York: M.E. Sharpe, 1989. 3-26.

Esherick, Joseph and Jeffrey Wasserstrom. "Acting Out Democracy: Political Theatre in Modern China." Wasserstrom and Perry. 32-69.

Foucault, Michel. The Archeology of Knowledge. Trans A.M. Sheridan Smith. New York: Pantheon, 1972.

Gray, Jack. Rebellions and Revolutions: China from the 1880s to 2000. Oxford: Oxford UP, 2002.

Han, Minzhu ed. Cries For Democracy: Writings from Tiananmen Square. Princeton: Princeton UP, 1990.

Hardt, Michael and Antonio Negri. Labor of Dionysus: A Critique of the State-Form. Minneapolis: UMP, 1994.

Kang, Liu. "Hegemony and Cultural Revolution." New Literary History 28.1 (1997): 69-86.

Lin, Chun. "China Today: 'Money Dissolves the Commune." New Left Review 201 (Sept-Oct 1993): 34-45.

Litzinger, Ralph. "Theorizing Postsocialism: Reflections on the Politics of Marginality in Contemporary China." South Atlantic Quarterly 101.1 (2002): 33-55

Lu, Ping et al., eds. A Moment of Truth: Workers' Participation in China's 1989 
Democracy Movement, and the Emergence of Independent Unions. Trans. Gus Mok et al. Hong Kong: HK Trade Union Education Centre, 1990.

Lukács, Georg. "Reification and the Consciousness of the Proletariat." History and Class Consciousness: Studies in Marxist Dialectics. Trans. Rodney Livingstone.

Cambridge, MA: MIT Press, 1971). 83-222. [1923]

Meisner, Maurice. Mao’s China and After: A History of the People's Republic. New York: The Free Press, 1986.

---. The Deng Xiaoping Era: An Inquiry Into the Fate of Chinese Socialism, 1978-1994.

New York: Hill and Wang, 1996.

Nathan, Andrew. "Epilogue." Children of the Dragon: The Story of Tiananmen Square.

Ed. Nathan, Orville Schell, and the Human Rights in China group. New York:

Collier Books, 1990. 215-16.

---. China's Transition. New York: Columbia UP, 1997.

Ogden, Suzanne et al. eds. China's Search for Democracy: The Student and Mass Movement of 1989. New York: M.E. Sharpe, 1992.

Perry, Elizabeth. “Casting a Chinese 'Democracy’ Movement: The Roles of Students, Workers, and Entrepreneurs." Wasserstrom and Perry. 74-92.

Said, Edward. Orientalism. New York: Penguin, 2003. [1978]

Saussy, Huan. Great Walls of Discourse and Other Adventures in Cultural China. Cambridge: Harvard UP, 2001.

Tong, Shen. Almost a Revolution: The Story of a Chinese Student's Journey from Boyhood to Leadership in Tiananmen Square. New York: Harper Collins, 1991.

Unger, Jonathan, ed. The Pro-Democracy Movements in China: Reports from the Provinces. New York: M.E. Sharpe, 1991.

Walder, Andrew and Gong Xiaoxia. "Workers in the Tiananmen Protests: The Politics of the Beijing Workers' Autonomous Federation." Australian Journal of Chinese Affairs. 29 (January 1993): 1-29.

Wang, Hui. "Contemporary Chinese Thought and the Question of Modernity." Trans. Rebecca Karl. Social Text 55 (1998): 9-44.

----. China's New Order: Society, Politics, and Economy in Transition. Trans Theodore Huters and Rebecca Karl. Cambridge: Harvard UP, 2003. 
Wasserstrom, Jeffery and Elizabeth Perry, eds. Popular Protest and Political Culture in Modern China. $2^{\text {nd }}$ Edition. Boulder: Westview Press, 1994.

Zhao, Dingxin. The Power of Tiananmen: State-Society Relations and the 1989 Beijing Student Movement. Chicago: UCP, 2001.

Zizek, Slavoj. "Against the Double Blackmail.” New Left Review 234 (1999): 76-82.

----. "A Leftist Plea for Eurocentrism.” Critical Inquiry 24 (Summer 1998): 30 pars. Expanded Academic ASAP. $<$ http://www.gale.com>. 20 March 2005. 